\title{
Census Return of Herakleides, Son of Didymos the Younger
}

James G. Keenan

Loyola University Chicago, jkeenan@luc.edu

Follow this and additional works at: https://ecommons.luc.edu/classicalstudies_facpubs

Part of the Classics Commons

\section{Recommended Citation}

Keenan, JG. "Census return of Herakleides, son of Didymos the younger" in Chronique d'Égypte 46, 1971.

This Article is brought to you for free and open access by the Faculty Publications and Other Works by Department at Loyola eCommons. It has been accepted for inclusion in Classical Studies: Faculty Publications and Other Works by an authorized administrator of Loyola eCommons. For more information, please contact ecommons@luc.edu.

\section{(c) (i) $\Theta \Theta$}

This work is licensed under a Creative Commons Attribution-Noncommercial-No Derivative Works 3.0 License. (c) Association Égyptologique Reine Elisabeth, 1971. 


\section{Census Return of Herakleides Son of Didymos the Younger*}

$\mathrm{A}^{\mathrm{Ln}}$

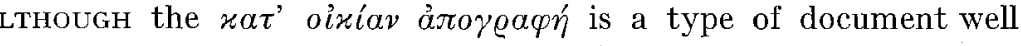
represented among the papyri of Roman Egypt ( $\left.{ }^{(}\right)$, the present text has a number of features which seem now to warrant treatment fuller than that allotted in its description at the back of $P$. Teb. Vol. II. The only extant return originating from the Fayum village Ibion Eikosipentarouron, it is submitted in absentia through a curator ( $\varphi$ oov-

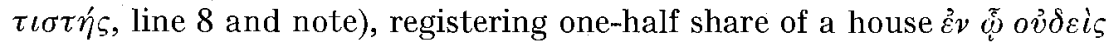

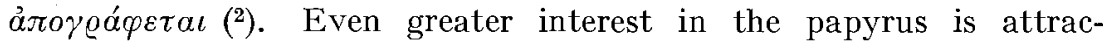
ted by the person for whom the return has been made, Herakleides, son of Didymos the younger, grandson of Herodes, a figure well attested in Tebtunis papyri of the second century. The pertinent texts are :

1. P. Mil. Vogl. IV 224 (7 Dec., A. D. 109). Herakleides lends 236 drachmas to Kronion son of Cheos, Kronion's wife Thenapynchis, and their children, Kronion and Taorsenouphis.

2. P. Mil. Vogl. IV 225 (26 May/24. June, A. D. $\left.120\left(^{3}\right)\right)$. Repayment of the preceding. Herakleides is described (lines 3-5) as :

(*) The papyrus belongs to the University of California at Berkeley and is in care of the Rare Books Department of the Bancroft Library. I am grateful to Mrs. Leslie Clarke and her staff for the opportunity to study and publish this text. My thanks also go to Dr. John C. Shelton for his valuable advice and suggestions on the content of this article.

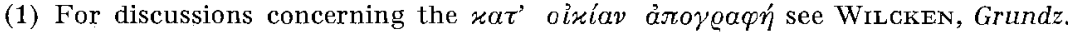
pp. 192ff ; S. L. Wallace, Taxation in Egypt from Augustus to Diocletian (Princeton 1938) pp. 96-115 ; M. Hombert-Cl. PrÉAux, Recherches sur le recensement dans l'Égypte romaine. ( $P$. Lugd.-Bat. V, Leyden 1952). Lists of relevant texts are given by Wallace pp. 392-95, more fully by Hombert-Préaux pp. 172-76. The latter list has been brcught more nearly up to date in $P$. Wisc. I p. 73 to which may now be added $B G U$ XI 2018-19, 2088-91, P. Oxy. XXXVI 2762, and P. Yale Inv. 1545 $\mathrm{A}, \mathrm{B}, \mathrm{C}$ (in $B A S P$ 7, 1970, pp. 87-98).

(2) I. e., it was unoccupied; WrLcken, Hermes 28 (1893) p. 242 ; Hombert-Préaux p. 114

(3) "121 d. C. ? " ed. The date is calculated by comparing the age descriptions given in the securely dated P. Mil. Vogl. 224 with those of P. Mil. Vogl. 225. Thenapynchis is 40 in the earlier text, 51 (?) in the later ; Taorsenouphis is 22 in the earlier,


$[\sigma \dot{\mu} \eta \tau \dot{\eta} \varsigma \mathrm{C}-\ldots-\ldots]$

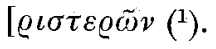

3. P. Teb. 512 descr. (ed. John 31) (26 April/25 May, A. D. 130 of 6200 drächmas and is styled $x\left[o ́ f \tau \omega v{ }^{2}\right)$. He is about 40 yea

4. P. Teb. 522 descr. edited be preceding text, Herakleides is $\mathrm{d}$ We learn further that he was regis the metropolis $\left({ }^{3}\right)$ and was a " $\varkappa \alpha ́ \tau$ of the 6475 are identical with per

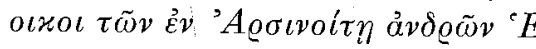
or as being $\dot{\varepsilon} x$ $\tau o \tilde{v} \dot{\alpha} \varrho \iota \theta \mu o \tilde{v} \tau o$ comprised an elite class of Fayu gistered in various quarters at th the synoikismos of Antinoopolis u but Herakleides was evidently $n$

33 (?) in the later. The eleven years able date of A. D: 120 for P. Mil. Vog descr. (in $B A S P$ 6, 1969, pp. 27-31) A. D. 130 . He was 30 years old at the

(1) The editor's restoration $x\left[o / \sigma \mu \eta \tau \eta \eta^{\prime}\right.$ upon whether the initial kappa is correct at the back of P. Mil. Vogl. IV, this le ternative reading ? $v \mid[\mu \nu \alpha \sigma i \alpha \varrho \chi o \varsigma$, based now be tried on the original.

(2) P. J. Sijpesteijn, Liste des gymnas (Amsterdam 1967) no. 52.

(3) For references to this amphodon,

(4) The equation was first made by Cf. P. Teb. $566+$ Archiv 6 pp. 144 an (5) P. Fam. Tebt. 29, 28.

(6) P. Fam. Tebt. 31, 1 and note. Mo

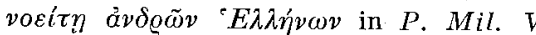

(7) Not necessarily meaning that all Oates, Bibliotheca Orientalis 23 (1966)

18) P. Fam. Tebt. 29, 27-28 and 50-52 Plaumann, supra n. 7 ; P. Meyer pp. 28 mann, Archiv 9 (1930) pp. 42-43; P. Mi pp. 136ff ; H. Braunert, Die Binnenwa 26, Bonn 1964) pp. 216, 220f, 230. 


\section{of Herakleides}

\section{os the Younger*}

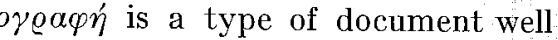
yri of Roman Egypt (1), the present es which seem now to warrant treatdescription at the back of $P$. Teb. inating from the Fayum village Ibion in absentia through a curator ( $\varphi \varrho o \nu-$ one-half share of a house $\dot{\varepsilon} \nu \tilde{\omega}$ ov̉s $i_{\zeta}$ nterest in the papyrus is attraceturn has been made, Herakleides, dson of Herodes, a figure well atecond century. The pertinent texts

A. D. 109). Herakleides lends 236 eos, Kronion's wife Thenapynchis, Taorsenouphis.

yy/24 June, A. D. $\left.120\left({ }^{3}\right)\right)$. Repayles is described (lines 3-5) as :

ersity of California at Berkeley and is in e Bancroft Library. I am grateful to Mrs. cunity to study and publish this text. My or his valuable advice and suggestions on

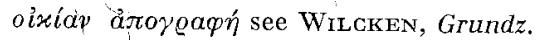
gypt from Augustus to Diocletian (PrinceRÉAUX, Recherches sur le recensement dans yden 1952). Lists of relevant texts are y by Hombert-Préaux pp. 172-76. The $\mathrm{p}$ to date in $P$. Wisc. I p. 73 to which may . Oxy. XXXVI 2762, and $P$. Yale Inv. 1545

Hermes 28 (1893) p. 242 ; Hombert-Préaux

ulated by comparing the age descriptions 24 with those of P: Mil. Vogl. 225. Thenahe later; Taorsenouphis is 22 in the earlier,



If

GENSUS RETURN OF HERAKLEIDES

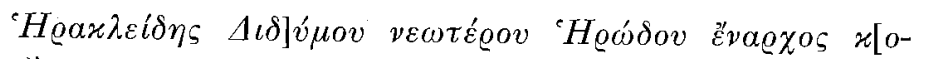

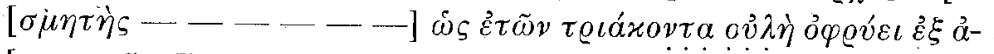



3. P. Teb. 512 descr. (ed. John C. Shelton in BASP 6, 1969, pp. 2731) (26 April/25 May, A. D. 130). Herakleides is creditor in a loan of 6200 drachmas and is styled (lines 9-10) $\tau \tilde{\omega} \nu \gamma \varepsilon \gamma v \mu\{\mu\} \nu \alpha \sigma \iota \alpha \varrho \chi \eta_{-}$ $\chi[o ́] \tau \omega \nu\left({ }^{2}\right)$. He is about 40 years old at this time.

4. P. Teb. 522 descr. edited below (4 Aug., A. D. 133). As in the preceding text, Herakleides is described as a former gymnasiarch. We learn further that he was registered in the Quarter of Tharapeia at

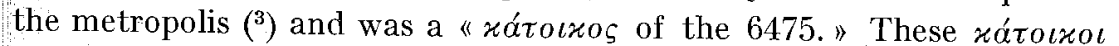
of the 6475 are identical with persons described in other texts as $x a ́ \tau$ -

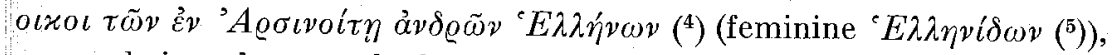

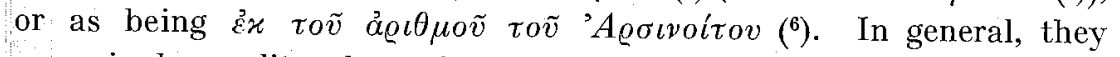
comprised an elite class of Fayum Greeks whose members were registered in various quarters at the metropolis $\left({ }^{7}\right)$. Some took part in the synoikismos of Antinoopolis under Hadrian in the early 130's $\left({ }^{8}\right)$, but Herakleides was evidently not among them.

33 (?) in the later. The eleven years which separate these ages suggest a prob able date of A. D. 120 for P. Mil. Vogl. 225, which is supported by $P$. Teb. 512 descr. (in $B A S P$ 6, 1969, pp. 27-31) where Herakleides' age is given as 40 in A. D. 130. He was 30 years old at the time of P. Mil. Vogl. 225 (see line 4).

(1) The editor's restoration $x[o / \sigma \mu \eta \tau \eta$ s, based upon P. Mil. Vogl. 226, depends upon whether the initial kappa is correctly read. To judge from the plate provided at the back of P. Mil. Vogl. IV, this letter is somewhat damaged. A possible al-

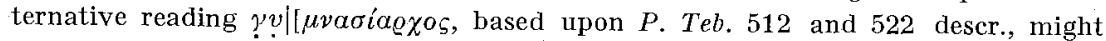
now be tried on the original.

(2) P. J. Sijpesteijn, Liste des gyymnasiarques des métropoles de l'Égypte romaine (Amsterdam 1967) no. 52.

(3) For references to this amphodon, Wörterbuch III Abschnitt 22, 410-11.

(4) The equation was first made by G. Plaumann, Archiv 6 (1920) pp. 176-83. Cf. P. Teb. $566+$ Archiv 6 pp. 144 and 222 (BL I p. 429).

(5) P. Fam. Tebt. 29, 28.

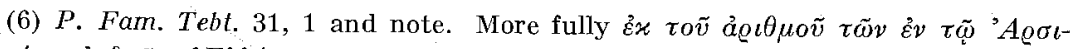

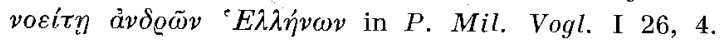

(7) Not necessarily meaning that all had their residences in the metropolis; Oates, Bibliotheca Orientalis 23 (1966) p. 265.

(8) P. Fam. Tebt. 29, 27-28 and 50-52;30,3-4 and 9-12. Further on the 6475, Plaumann, supra n. 7 ; P. Meyer pp. 28ff.; P. Cornell I 16 introduction; Bickermann, Archiv 9 (1930) pp. 42-43; P. Mil. Vogl. I pp. 221-22 ; Bell, JRS 30 (1940) pp. 136ff; H. Braunert, Die Binnenwanderung (Bonner Historische Forschungen 26, Bonn 1964) pp. 216, 220f, 230. 
5. P. Mil. Vogl. IV 226 (25 July/23 August, A. D. 135). Herakleides

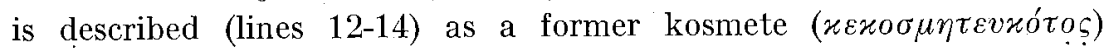
and as deceased husband of his wife Aphrodisia. The text is the repayment of a loan of 20 artabs of wheat. The original creditor was Herakleides' mother (name missing, line 11), who has presumably died, having passed on to Herakleides the right to recover the loan. He has died in turn, having bequeathed the same right $x \alpha \tau \dot{\alpha} \delta \iota \alpha-$ $\theta \eta \dot{x} \eta v$ (line 19) to Aphrodisia.

A brief sketch of Herakleides' life can be drawn from the five texts just listed. Born about A. D. 90 into an established family of Arsinoite Hellenes, in his private business dealings he is seen from an early age $(\mathbf{1})$ as creditor in loans to persons residing in Tebtunis ( $P$. Mil. Vogl. 224 ; cf. P. Teb. 512). He owned half share of a house at Ibion Eikosipentarouron (P. Teb. 522), but this was not his or his family's

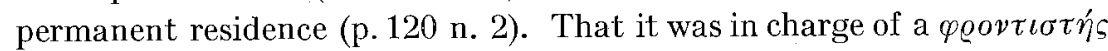
leads to speculation that his holdings in and about the Ibion were more extensive than the present state of our evidence can confirm (infra line 8 note). Herakleides' public life was marked by liturgic service, as gymnasiarch ( $P$. Teb. 512 and 522) and as kosmete ( $P$. Mil. Vogl. $225\left(^{2}\right)$ and 226). His death occurred between 13 July, A. D. 134, the day his will was drawn (P. Mil. Vogl. 226, 19-21), and August of A. D. 135 (P. Mil. Vogl. 226), when he would have been 44-45 years of age. Since his wife was roughly 20 years his junior (P. Mil. Vogl. 226, 5), the marriage must have taken place comparatively late in Herakleides' lifetime. It is not known whether it had any issue.

There are a few texts which concern contemporary members of Herakleides' family :

1. P. Teb. 531 and 532 descr. (in BASP 7, 1970, pp. 77-86 (3)) (22 June, A. D. 133). Two loans drawn on the same day, one for 1300 drachmas, the other for 1200 . The creditor in both texts is named Herodes also called Diogenes, son of Didymos the younger. About 48 years old at this time, therefore born about A. D. 85 , he is a former

(1) He would have been about 19 years old at the time of P. Mil. Vogl. 224.

(2) If the reading is correct; vide p. $121 \mathrm{n} .1$.

(3) The readings of these texts can be made more nearly accurate: 531,4 :

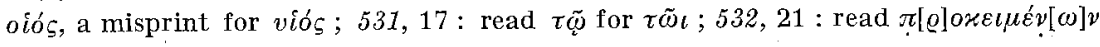
instead of $\pi[\varrho] \circ x \varepsilon \iota \mu \varepsilon v[\omega \nu]$. gymnasiarch $\left({ }^{1}\right)$. There is a grea served as one of the $\beta \iota \beta \lambda \iota \% \varphi v$ ' Nome in A. D. $130 / 1\left(^{2}\right)$ and little Herakleides.

2. P. Fam. Tebt. 9 (22 Nov., A of a loan originally taken out in jan's 8th year (9 Aug., A. D. 105 diaina; but since she has (appare is repaid to her brother and siste

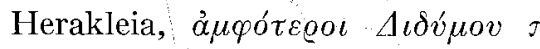
'H@ósov (line 5). Prof. van Groni into his P. Fam. Tebt. "pedigree may now with reasonable certit to the persons known from the formation from these latter papy P. Fam. Tebt. 9 and the stemma larged as follows:

\section{$\mathrm{Hel}$}

[Thae]sis $=$ Didymos the elder

Herodiaina Herakleides
(d. 105/7)
(b. 80 )

Didymos = Apia-Herakl (b. 61)

(b. 69)

The family appears to be descen printed as Table II in $P$. Mich. our stemma, may be (though this Herodes, son of Herakleides who is

(1) Sijpesteijn Liste no. 49.

(2) Sijpesteijn ibid., N. Lewis, Proc. p. 150 for references. Add now $B G U \mathrm{X}$

(3) For a discussion of the Michigan see in particular P. Mich. 276 (A. D. 47) cerning this family is $P$. Mich. Shelton 6 


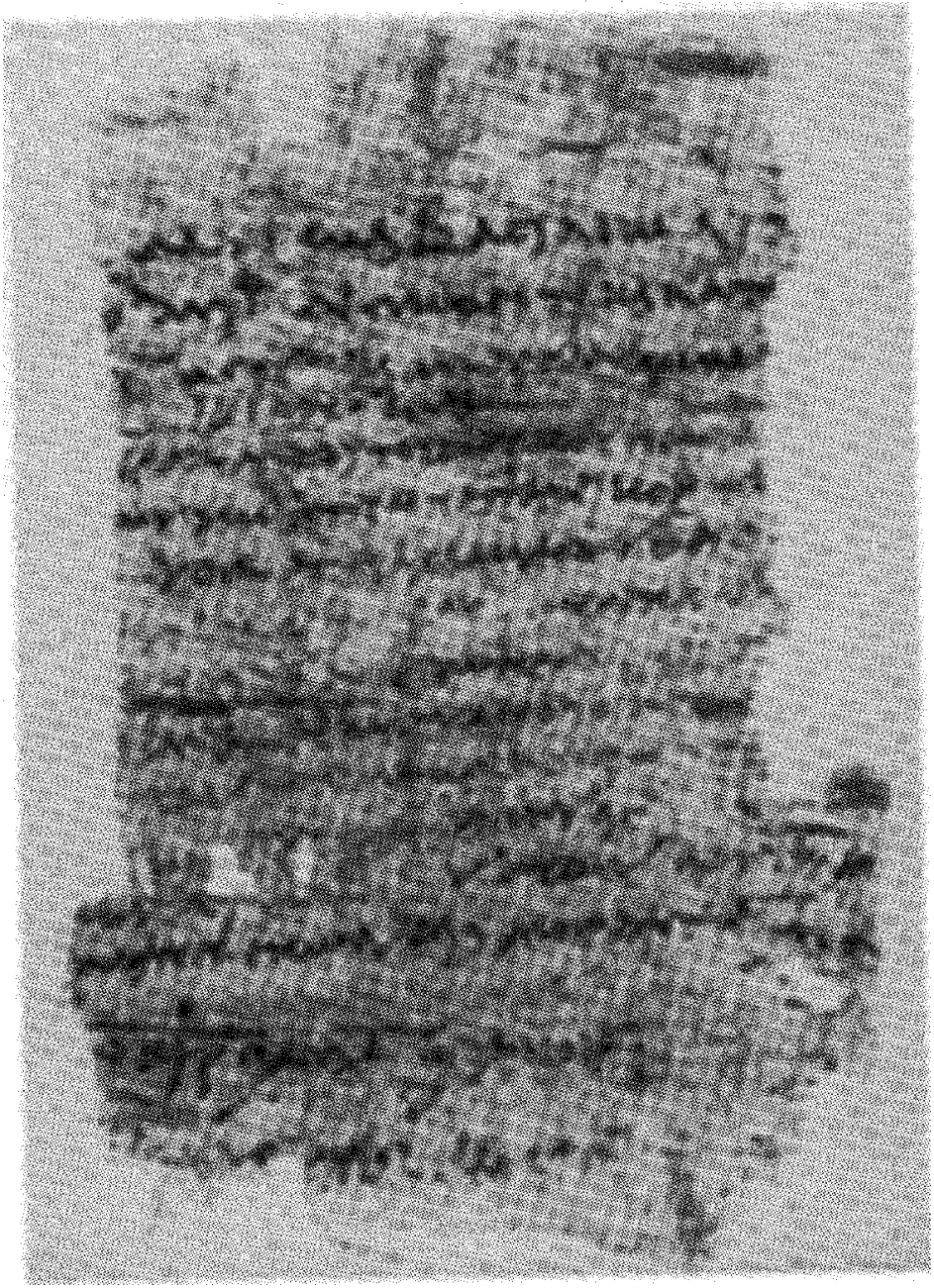

Fig. 1. - P. Teb. 522. Census-Return (A.D. 133)

sibly) concern descendents of the Michigan stemma, but I am not able at present to place them in definite relationship to P. Fam. Tebt. 9, the Berkeley and the Milan

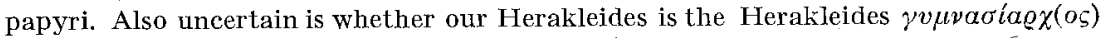
(Sijpesteijn Liste no. 220) listed in P. Mil. Vogl. II 103 (=SB VI 9378) 23 as owning 16 arouras (probably near Tebtunis) which had been flooded; or whether he is

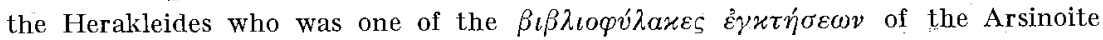
Nome in A. D. 120/1 (Sijpesteijn Liste no. 35). Both identifications are possible, but unprovable.
The text is nearly complete, tho and ends of most of its lines. Li the first half of line 12, consider of the readings or restorations a the text remains undisturbed.

P. Teb. 522 descr.

$8.4 \times 12.7 \mathrm{~cm}$.

$1[\Pi \pi \tau o] \lambda \varepsilon \mu \alpha \iota \omega \iota \beta \alpha \sigma \iota \iota \varkappa \tilde{\omega} \iota$ $[\Pi]] \circ \lambda(\dot{\varepsilon} \mu \omega v o \varsigma) \mu \varepsilon \rho i \delta(o \varsigma) \delta t$ $[\tau \tilde{\eta} \varsigma \alpha] \dot{v} \tau(\tilde{\eta} \varsigma) \mu \varepsilon \varrho i \delta(\circ \varsigma) x$

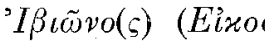

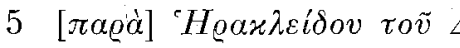

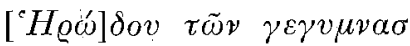

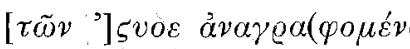

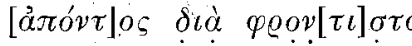
[.....]

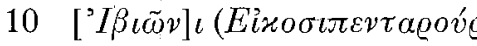

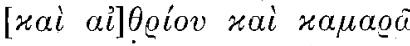

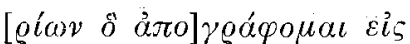


$[\dot{\alpha} \pi 0] \gamma \varrho \alpha \varphi \dot{\eta} v \quad \dot{\varepsilon} v \quad \tilde{\omega}$ ov̉deis

15. $[\mu \alpha \tilde{\imath}] \circ \varsigma \beta \alpha(\sigma \iota \lambda \iota x \dot{\varrho} \varsigma) \gamma \varrho(\alpha \mu \mu$

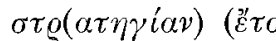

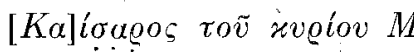
$2 \delta \iota \varepsilon ́ \pi 0 \nu \tau \iota: o$

"To Ptolemaios, basilikogramn the Arsinoite Nome, discharging same Meris, and to Melas, komog ron, from Herakleides, son of Did rodes, formerly gymnasiarch, kat Quarter of Tharapeia, in absenti 
The text is nearly complete, though it lacks letters at the beginnings and ends of most of its lines. Lines 8-9 are rather severely abraded, the first half of line 12, considerably damaged. Still, though details of the readings or restorations are sometimes in doubt, the sense of the text remains undisturbed.

P. Teb. 522 descr.

Tebtunis

$8.4 \times 12.7 \mathrm{~cm}$.

A.D. 133

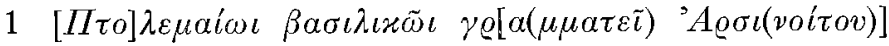



$\left[\tau \tilde{\eta}_{\varsigma} \alpha\right] \dot{j} \tau(\tilde{\eta} \varsigma) \mu \varepsilon \varrho i \delta(o \varsigma) x a i \quad M \varepsilon \lambda a v \tilde{a} x \omega \mu o[\gamma \varrho \alpha(\mu \mu \alpha \tau \varepsilon \tilde{\imath})]$

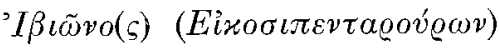

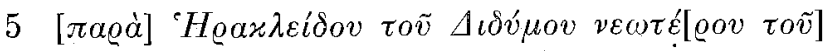

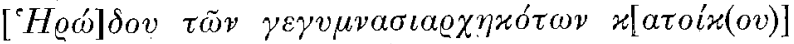

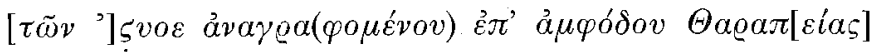



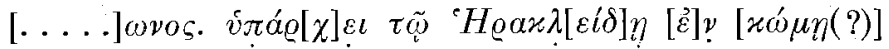



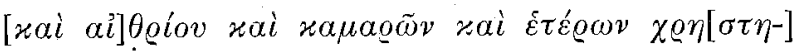



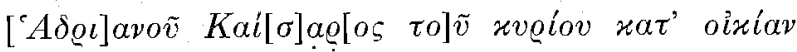



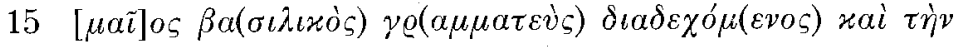

$\sigma \tau \varrho\left(\alpha \tau \eta \gamma^{\prime} \alpha \alpha\right)$ (हैं

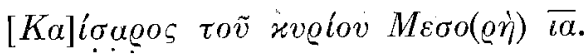

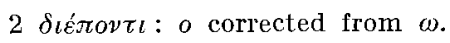

in stemma, but I am not able at present . Fam. Tebt. 9, the Berkeley and the Milan akleides is the Herakleides $\gamma v \mu \nu \alpha \sigma i \alpha \varrho \chi(o s)$ Vogl. II 103 ( = SB VI 9378) 23 as owning ich had been flooded; or whether he is $3 \lambda \iota \sigma \varphi v \lambda \alpha x \varepsilon \varsigma \varepsilon \dot{\varepsilon} \gamma \tau \tau \dot{\eta} \sigma \varepsilon \omega \nu$ of the Arsinoite o. 35). Both identifications are possible, 
on. Tliere belongs to Herakleides in the village (?) Ibion Eikosipentarouron one-half portion of a house and courtyard and open-air hall and storage vaults and other appurtenances which I register for the house by house registration of the past year 16 of Hadrianus Caesar the lord, in which no one is registered. (2nd hand) Ptolemaios, basilikogrammateus, discharging also the office of strategos. Year 17 of Hadrianus Caesar the lord, Mesore 11."

1-4. I reproduce the transcription of the $P$. Teb. II editors. For Ptolemaios see V. Martin, Archiv 6 (1920) pp. 167-68, esp. p. 167 n. 6 ; H. Henne, Liste des stratèges des nomes égyptiens à l'époque gréco-romaine (Mémoires de l'Institut français d'Archéologie orientale du Caire LVI, 1935) pp. 61 and 72 ; G. Mussies, Supplément à la liste des stratèges des només égyptiens de H. Henne, P. Lugd.-Bat. XIV (1965) p. 31 (no. 388). He is known as basilikogrammateus of the Polemonos Meris from 31 Jan., A. D. 131 (P. Teb. II $374=$ WChr 349). His name has been restored as basilikogrammateus in $P$. Teb. II 566 descr., a census return from Samareia submitted earlier in the same year as the present text. He is known as basilikogrammateus and acting strategos from our text (4 Aug., A. D. 133) and from SB VI 9312 (date lost).

2. The hand is somewhat larger in the opening lines than down below ; as a result, the lacuna does not seem large enough to accomodate $\tau \dot{\eta} v \sigma \tau \varrho \alpha\left(\tau \eta \gamma^{\prime} \alpha \nu\right)$ or $\tau \dot{\eta} \nu$ $\sigma \tau \varrho\left(\alpha \tau \eta \gamma^{\prime} \alpha \nu\right)$. The use of the article was standard, but not invariable; cf. P. Oxy. I 62, 2-3 and XII 1498, 6. The scribe also neglected to include $\tau \alpha$ before $x \alpha \tau \alpha$, so that line 2

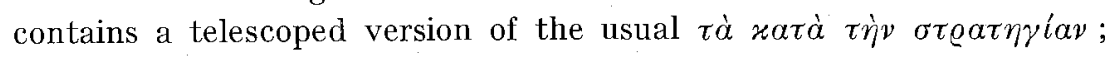
for references to which see Wörterbuch III Abschnitt $8 \mathrm{~s}$. v. $\sigma \tau \varrho \alpha \tau \eta \gamma i \alpha$.

4. 'I $\beta \iota \tilde{\omega} \nu$ : 'I $I \beta \omega \nu \iota$ edd. On the formation of the word and its correct accent see W. Crönert, WKP 18 (1903) cols. 484-85. The village Ibion Eikosipentarouron was located in the Gharaq district of the Polemonos Meris according to P. Teb. II p. 380. It is not, however, to be identified with the modern Medinet Madi, now known to be the ancient Narmouthis : Chr. d'Ég. 14 (1939) p. 88 ; A. Grohmann, From the World of Arabic Papyri (Cairo 1952) pp. 10 and 214 n. 11.

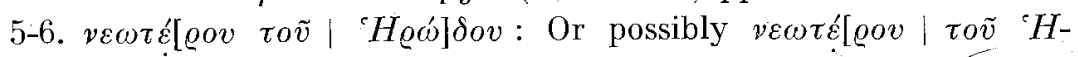
$\varrho \omega ́] \delta o v$.

6. $x[a \tau o i x(o v)]$ : Commonly abbreviated in this fashion (e. g., $B G U$ II 487,6 ; III 792,11 ), and printed this way here so as to fit the lacuna more exactly.
8. $[\alpha 3 \pi o ́ v \tau] \circ \varsigma$ : I. e., Tyrannos' p to that of the Roman curator abse schlag, The Law of Greco-Roman 1 ed. Warsaw 1955) p. 181 n. 25. 5 and $14 ; B G U$ II 493 Col. II 16 20,7 ; P. Wisc. 14,4 . On return lace, Taxation pp. $100 \mathrm{f}$ and Ho censement pp. 59-62. It is unli were limited to half share of a 1 was probably vested in land, som vicinity of Ibion Eikosipentarour Tebt. pp. 12-13) of land and buil Fam. Tebt. pedigree is instructive Tebt. 23 which shows that perso Herakleides had interests in land rouron.

9. [....]wvos: Either a patr the preceding line; or a double restored at the end of line 8 .

10. $\alpha \dot{v} \lambda \tilde{\eta} \varsigma]$ : Perhaps abbrevia xias xai aviñs is extremely con s. v. oixi $\alpha$ ). For oixias xai $\alpha \hat{v} \lambda \tilde{\eta}$ (in $B A S P 7,1970,87 \mathrm{ff}$ ) $12,33-3$ 257,$7 ; 284,8$.

11. ai] 0 óov: Written rather reading of the last four letters is gl in line 13. "It is the light-shaft a house " $-P$. Wisc. I 18, 8 note A. R. Schütz, Der Typus des he Giessen 1936) p. 34.

$\varkappa \alpha \mu \alpha \varrho \tilde{\omega} \nu:$ Storage vaults 》; cf theft, in which (lines 6ff) the injur that items had been stolen : $\dot{\varepsilon} \gamma \varepsilon v o$,

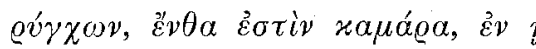

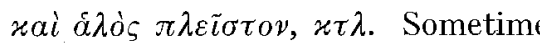
as being located "in the cellar" p. 233, 12). Kellerraum, Kellerg the definitions given in Wörterbuc 
In the village (?) Ibion Eikosipentase and courtyard and open-air hall ppurtenances which I register for of the past year 16 of Hadrianus registered. (2nd hand) Ptolemaios, also the office of strategos. Year: Mesore 11.»

ion of the $P$. Teb. II editors. For (1920) pp. 167-68, esp. p. 167 n. 6 ; nomes égyptiens à l'époque gréco-roçais d'Archéologie orientale du Caire ssies, Supplément à la liste des stranne, P. Lugd.-Bat. XIV (1965) p. 31 likogrammateus of the Polemonos Ceb. II $374=$ WChr 349). His name nmateus in $P$. Teb. II 566 descr., bmitted earlier in the same year as as basilikogrammateus and acting D. 133) and from $S B$ VI 9312 (date

$r$ in the opening lines than down s not seem large enough to accomo$\varrho\left(\alpha \tau \eta \gamma^{\prime} \alpha \nu\right)$. The use of the article cf. P. Oxy. I 62, 2-3 and XII 1498, 6 . ade $\tau \alpha$ before $x \alpha \tau \alpha$, so that line 2 he usual $\tau \dot{\alpha} \varkappa \alpha \tau \dot{\alpha} \tau \dot{\eta} \nu \sigma \tau \varrho \alpha \tau \eta \gamma \dot{\alpha} \alpha \nu$; uch III Abschnitt 8 s. v. $\sigma \tau \varrho \alpha \tau \eta \gamma i \alpha$. he formation of the word and its KP 18,(1903) cols. 484-85. The villocated in the Gharaq district of . Teb. II p. 380. It is not, however, Medinet Madi, now known to be Ég. 14 (1939) p. 88 ; A. Grohmann, (Cairo 1952) pp. 10 and 214 n. 11.

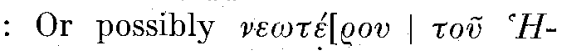

eviated in this fashion (e. g., $B G U$ d this way here so as to fit the la-

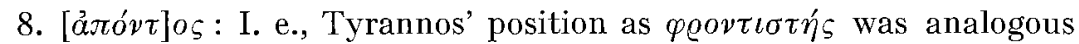
to that of the Roman curator absentis; see P. Meyer p. 57, R. Taubenschlag, The Law of Greco-Roman Egypt in the Light of the Papyri (2nd ed. Warsaw 1955) p. 181 n. 25. For the restoration ef. PSI IX 1064, 5 and $14 ; B G U$ II 493 Col. II $16 ; B G U$ VII 1581,$7 ; P$. Fam. Tebt. 20,$7 ; P$. Wisc. 14,4 . On returns made through intermediaries, Wallace, Taxation pp. $100 \mathrm{f}$ and Hombert-Préaux, Recherches sur le recensement pp. 59-62. It is unlikely that Tyrannos' responsibilities were limited to half share of a house. Much of Herakleides' wealth was probably vested in land, some of which would have been in the vicinity of Ibion Eikosipentarouron. Van Groningen's list (P. Fam. Tebt. pp. 12-13) of land and buildings owned by members of the $P$. Fam. Tebt. pedigree is instructive. Especially tantalizing is P. Fam. Tebt. 23 which shows that persons who may have been related to Herakleides had interests in land in the vicinity of Ibion Eikosipentarouron.


the preceding line; or a double name, in which case $x \alpha i$ should be restored at the end of line 8 .

10. $\alpha \hat{v} \lambda \tilde{\eta} \varsigma]$ : Perhaps abbreviated $\alpha \hat{v}^{3} \lambda(\tilde{\eta} s)$. The collocation oixias $x \alpha i$ $\alpha \dot{v} \lambda \tilde{\eta} \varsigma$ is extremely common in the papyri (Wörterbuch II

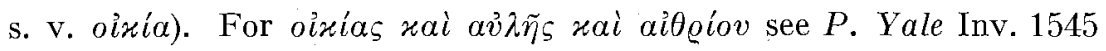
(in $B A S P 7,1970,87 \mathrm{ff}) 12,33-34 ; P$. Lips. 16, 10-11; cf. P. Strasb. 257,$7 ; 284,8$.

11. $\alpha i] \theta \varrho i o v:$ Written rather quickly, but the correctness of the reading of the last four letters is guaranteed by comparison with xv@iov in line 13. "It is the light-shaft/central courtyard in the middle of a house $\gg-$ P. Wisc. I 18, 8 note. Cf. P. Oxy. XXIV 2406 (p. 143); A. R. Schütz, Der Typus des hellenistisch-ägyptischen Hauses (Diss. Giessen 1936) p. 34.


theft, in which (lines 6ff) the injured party explains how she discovered

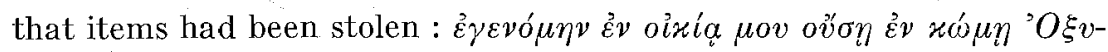



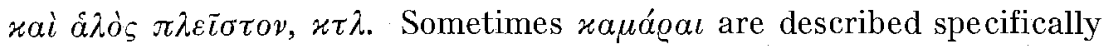

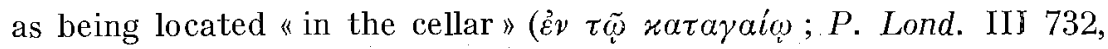
p. 233, 12). Kellerraum, Kellergewölbe, Vorratskammer are among the definitions given in Wörterbuch; see also Schütz pp. 58ff. 
12. $\delta \iota \varepsilon \lambda\left(\eta \lambda v \theta \delta^{\tau} \sigma \varsigma\right):$ Not $\delta \iota \varepsilon \lambda(\theta o ́ v \tau o \varsigma)$. The former was standard in the Arsinoite, the latter, in the Oxyrhynchite Nome ; Hombert-Préaux pp. 79ff. On returns made the year following the declared census year see Wallace Taxation p. 395 ; Hombert-Préaux, Chr. d'Ég. 19 (1944) pp. 147-50; Recherches sur le recensement pp. 77-84. The 16 th year of Hadrian is A. D. 131/2.

15-16. The date is 4 Aug., A. D. 133.

University of California, Berkeley

James G. KEENAN
Le $P$. IFA $O$ II 1 , daté du 28 no lettre de Bion à son associé Nican mais les lacunes relativement brèv tes à première vue, grèvent en $r$ cument d'une incertitude fondame dans tout cela? Qui prend en che

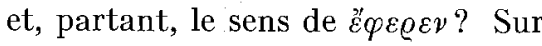
dr. prévues à la ligne 5 ? La traduc Wagner nous donne avec son com que ce texte obscur se dérobe à tor qu'il est mal rédigé, soit parce qu titude, soit parce que ces deux rais point de départ le texte auquel

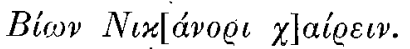

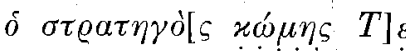

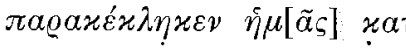

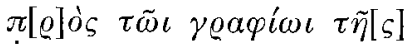

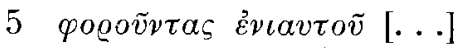

(1) Guy Wagner, Papyrus grecs de II (Le Caire, 1971). Cf. ci-dessous le co 